\title{
Workplace change process and satisfaction with activity-based office
}

\author{
Pia Sirola, Annu Haapakangas, Marjaana Lahtinen and \\ Virpi Ruohomäki \\ Finnish Institute of Occupational Health, Helsinki, Finland
}

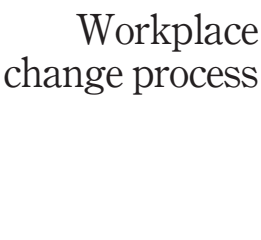

Received 11 December 2020 Revised 13 May 2021

17 June 2021

Accepted 27 June 2021

\begin{abstract}
Purpose - The purpose of this case study is to investigate how the personnel in an organization experienced the process of change when moving from private offices to an activity-based office (ABO) and how their perceptions of change were associated with changes in their satisfaction with the work environment a year after relocation.

Design/methodology/approach - A comparative pre-post study design and mixed methods were used. Survey data was obtained from 154 employees before the relocation and 146 after the relocation. The data on the 105 employees who responded to both surveys were statistically analyzed. Representatives of different units were interviewed $(n=17)$ and documentary material was analyzed as complementary material.

Findings - The personnel's criticisms concerned the reasons for the change, their opportunities to influence the office design and the extent to which their views were taken into account. Environmental satisfaction decreased after moving to the ABO. The personnel's ratings of the workplace change process before the relocation were associated with the later change in environmental satisfaction. Based on logistic regression, the degree of agreement with management's reasons for the change was the strongest predictor of the change in environmental satisfaction.

Practical implications - Organizations that move from private offices to an ABO should invest in highquality change management and simultaneously develop both work and facilities. Special attention should be paid to clarifying the rationale for the change to the employees and to providing them with opportunities to influence during the change. Organizations should continue to monitor user experiences and evaluate the effects of the change after the office redesign and should take corrective action as needed.

Originality/value - This empirical case study is unique as it combined qualitative and quantitative methods and investigated the process of relocation and its outcomes in a one-year follow-up. This approach captured the importance of managing change and assessing the long-term effects of office redesign when moving from private offices to an $\mathrm{ABO}$.
\end{abstract}

Keywords Workplace change management, Process, Activity-based office, Personnel experience, Environmental satisfaction

Paper type Research paper

(C) Pia Sirola, Annu Haapakangas, Marjaana Lahtinen and Virpi Ruohomäki. Published by Emerald Publishing Limited. This article is published under the Creative Commons Attribution (CC BY 4.0) licence. Anyone may reproduce, distribute, translate and create derivative works of this article (for both commercial and non-commercial purposes), subject to full attribution to the original publication and authors. The full terms of this licence may be seen at http://creativecommons.org/licences/by/4.0/legalcode

The study is part of the "Spatial Solution for Environmental Satisfaction, Well-Being and Work Engagement in Activity-Based Offices" - project, funded by the Academy of Finland (Project number 3552801).

Authors would like to thank statistician Maria Hirvonen MSc (statistics), Finnish Institute of Occupational Health for guiding authors with the statistical analysis.

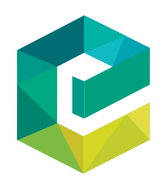

Facilities

Vol. 40 No. 15/16, 2022 $15 / 16,2022$
pp. $17-39$

Emerald Publishing Limited 0263-2772 
$\mathrm{F}$

$40,15 / 16$

\section{Introduction}

Today, work is characterized by a technological revolution, which enables knowledge workers to work independently of time and space (Lee and Brand, 2005), meaning that work is increasingly flexible and multi-locational (Vartiainen et al., 2007; AppelMeulenbroek et al., 2011; Harris, 2016; Wohlers and Hertel, 2017). This has resulted in less use of office space, which has often led organizations to modify their premises to better suit multi-locational work (Vartiainen et al., 2007; Blok et al., 2012; Kämpf-Dern and Konkol, 2017). Activity-based offices (ABOs) are an example of modern work environments that organizations adopt to support communication and collaboration, reduce facility costs and reach energy and space efficiency targets (Golden, 2007; Appel-Meulenbroek et al., 2011; Seddigh et al., 2014; Kim et al., 2016; Wohlers and Hertel, 2017).

Activity-based work environments vary in terms of office design and the definitions used in the literature (Bodin Danielsson et al., 2015; Lahtinen et al., 2015; Wohlers et al., 2019). An ABO is typically described as a flexible solution that has different spaces or zones for different types of activities, usually consisting of open spaces for teamwork, silent spaces for tasks that require concentration, spaces for phone calls and formal and informal meeting areas. In ABOs, employees usually have no assigned desks but switch between workspaces according to task-related needs (De Croon et al., 2005; Golden, 2007; Appel-Meulenbroek et al., 2011; Bodin Danielsson et al., 2015). However, activitybased workspace practices can also be applied in offices with assigned desks (Haapakangas et al., 2018), in which case they are referred to as combi-offices (De Been and Beijer, 2014) or multi-space offices (Lahtinen et al., 2015). This type of ABO design has been studied less.

\section{Activity-based offices and employee satisfaction}

The interest in investigating how different office types affect employees goes back many years and has a long research tradition (Bodin Danielsson and Bodin, 2009; De Croon et al., 2005; Nemecek and Grandjean, 1973; Oldham and Brass, 1979; Pejtersen et al., 2006; Zalesny and Farace, 1987). Environmental satisfaction is a commonly used indicator of the perceived quality of workspaces, as it is associated with, for example, job satisfaction (Newsham et al., 2009) and mental and physical well-being at work (Herbig et al., 2016). The ABO design is marked by positive expectations of various benefits for organizations and individuals (van Koetsveld and Kamperman, 2011) because it aims to facilitate more flexible working methods, with parallel changes in organizational culture and management supporting this transformation (Nijp et al., 2016). These goals and assumptions have prompted researchers to compare ABOs to traditional office designs (i.e. private, shared and open-plan offices with assigned desks), typically using cross-sectional methods (Bodin Danielsson and Bodin, 2009; Bodin Danielsson et al., 2015; De Been et al., 2015; Kim et al., 2016) or before-after comparisons during office relocations (Gerdenitsch et al., 2017; Haapakangas et al., 2019; Morrison and Stahlmann-Brown, 2021).

A systematic review by Engelen et al. (2019) associated ABOs with several positive outcomes, including workspace satisfaction and considered it "a promising concept." However, this conclusion appears to mainly apply to cases in which employees move to an ABO from shared or open-plan offices (Arundell et al., 2018; Blok et al., 2009, 2012; Gerdenitsch et al., 2017; Robertson et al., 2008; van der Voordt, 2004). Moving from private offices has been researched less and has resulted in more negative observations (Morrison and Stahlmann-Brown, 2021; Haapakangas et al., 2019; Ruohomäki et al., 2019). These 
negative findings have related particularly to distractions and lack of privacy (Engelen $e$ al., 2019). Furthermore, satisfaction levels in individual ABOs vary substantially (Brunia et al., 2016; van der Voordt, 2004). To reliably evaluate the effects of the ABO concept on employees, we must understand which factors, in addition to the physical office design, contribute to the perception of ABOs. One such factor is the perception of the implementation and management of workplace change.

\section{Management of workplace changes}

As in successful organizational changes (Lewin, 1951; Kotter, 1996; Hayes, 2018), change management also plays a key role in workplace changes (Laframboise et al., 2003; van der Voordt, de Been and Maarleveld, 2012; Finch, 2012; Lahtinen et al., 2015, 2017; Kämpf-Dern and Konkol, 2017; Ruohomäki et al., 2017; Bergsten et al., 2021). This issue is typically ignored in quantitative relocation studies (Blok et al., 2009; Meijer et al., 2009; Haapakangas et al., 2018), even though the perception of change management has been shown to contribute to employee outcomes when moving to an ABO (Bull and Brown, 2012; Brunia et al., 2016; Bergsten et al., 2021; Rolfö, 2018; Wijk et al., 2020). For example, the perceived meaningfulness of the office redesign (Wijk et al., 2020), sufficient information regarding the change (Brunia et al., 2016; Rolfö, 2018; Babapour, 2019) and the quality of communication (Bull and Brown, 2012) have been associated with environmental satisfaction after relocation to an ABO. To understand the outcomes of the change, it is essential to evaluate what was done in the process itself and to understand the experiences and perceptions during the change events (Nielsen and Randal, 2013). Investigating the relation between the process and outcomes of office relocation requires a multi-method approach that combines quantitative and qualitative methods. To date, only a few such studies have been conducted on the implementation of ABOs (Ruohomäki et al., 2017; Rolfö, 2018; Wijk et al., 2020). Various frameworks (Laframboise et al., 2003; Finch, 2012; van der Voordt, 2003; Visher, 2012; Kämpf-Dern and Konkol, 2017) and other publications (van der Voordt, de Been and Maarleveld, 2012; Lahtinen et al., 2015, 2017; Brunia et al., 2016) have identified the elements of successful workplace change management. These publications show that there is no general model for a successful workplace change, as the model would have to fit the context, goals and individual needs (Finch, 2012; Bodin Danielsson et al., 2015). As regard ABOs, several researchers have highlighted the need to identify and investigate relevant change management issues (Gerdenitsch et al., 2017; Rolfö, 2018; Wijk et al., 2020; Bergsten et al., 2021; Babapour, 2019).

In many cases, workplace changes fail to achieve their intended outcomes (Joroff, 2002; Lahtinen et al., 2015, 2017; Kämpf-Dern and Konkol, 2017), especially from the employee perspective (Bull and Brown, 2012; Morrison and Stahlmann-Brown, 2021; Haapakangas et al., 2019; Ruohomäki et al., 2019). This may be due to the multidimensional nature of workplace changes (Finch, 2012; Lahtinen et al., 2015). Moving to an ABO leads not only to changes in physical workspaces but also to deeper changes in the way in which individuals work and in organizational culture and leadership (Blok, 2012). It involves major visible, compelling changes that have more direct effects on the everyday activities of employees than many other organizational changes. Employees often experience these kinds of workplace changes as emotionally challenging and this can lead to strong resistance (Laframboise et al., 2003; Finch, 2012; Kämpf-Dern and Konkol, 2017), which is typically associated with a fear of losing one's own territory. One of the shortcomings of these changes is that workplace change projects are not managed in a way that makes them empowering for employees (Visher, 2012). Workplace change management is not only a 
$\mathrm{F}$

$40,15 / 16$

question of technically managing the phases of the process but it is also a question of supporting employees during all the phases of planning, implementation, operation and evaluation (Finch, 2012). Organizing the workplace change process calls for change management practices that promote dialogue and help users experience the whole process as comprehensive, manageable and meaningful, thus supporting their sense of coherence (Ruohomäki et al., 2015; Wijk et al., 2020; Antonovsky, 1996), feelings of readiness (Laframboise et al., 2003; Finch, 2012) and commitment to change (Finch, 2012; van der Voordt et al., 2012; Lahtinen et al., 2015; Kämpf-Dern and Konkol, 2017).

One common challenge in workplace changes is that space and organizational changes may be implemented in separate projects, with no dialogue between them (Joroff, 2002; Finch, 2012; Lahtinen et al., 2015; Ruohomäki et al., 2017). This can lead to difficulties in clearly understanding the context of change and integrating deeper organizational changes into spatial changes (Finch, 2012). Further, if change management concerns facility management alone, it may lead to insufficient provision of concrete change support (Ruohomäki et al., 2017) and isolation of user-driven information (Joroff, 2002; Finch, 2012; Visher, 2012; Lahtinen et al., 2015; Ruohomäki et al., 2017). Failure to involve users in the design may lead to a poor fit between employees' work requirements and the work environment, which has shown to be important for various employee outcomes, such as increased interaction and satisfaction (Gerdenitsch et al., 2017), as well as task performance (Hoendervanger et al., 2019). All this entails risks for the success of the process.

\section{The present study}

As the literature reviewed above shows, research on the process of change and its effects on employee satisfaction using mixed methods is lacking in the context of ABOs. In addition, such changes require long follow-up periods, as they involve profound changes in organizational culture and employee behavior. The follow-up periods of most previous relocation studies have been less than one year (Rolfö, 2018; Wijk et al., 2020; Gerdenitsch et al., 2017: Arundell et al., 2018; Blok et al., 2012), with a few exceptions (Bergsten et al., 2021; Haapakangas et al., 2019; Meijer et al., 2009).

The aim of this study was to analyze the effects of workplace change on environmental satisfaction with the $\mathrm{ABO}$ and to investigate whether the perceptions of the workplace change process before the relocation were associated with the change in environmental satisfaction one year after the relocation. The study concerned an organization that moved from private offices to an $\mathrm{ABO}$ but retained assigned desks. A further aim was to investigate how the workplace change process was implemented and to evaluate the personnel's experiences of the process. The focus was on the positive and negative perceptions of workplace change.

The specific research questions were:

$R Q 1$. How was the workplace change implemented?

$R Q 2$. How did the personnel (i.e. employees, including managers) evaluate the change process?

RQ3. Was satisfaction with the work environment affected by the workplace change?

$R Q 4$. Were the perceptions of the change process before the relocation associated with later changes in environmental satisfaction? 


\section{Material and methods}

Study design

This study investigated the relocation of a public administration office from private offices to an

ABO. It used quantitative and qualitative methods at different time points of the process. A questionnaire was administered three months before (in 2015) and 12 months after the relocation (in 2016). A comparative pre-post design was applied to the analysis of the questionnaire data, with environmental satisfaction as the dependent variable. The qualitative methods included interviews (a month before the relocation) and the evaluation of documentary material concerning the process implementation. The study was ethically approved by Ethics Board of the Finnish Institute of Occupational Health.

\section{Description of environmental change in the case organization}

The participating organization underwent a strategic workplace change from private offices to an ABO. The change began in January 2013 and the organization moved to the new premises in May 2015. The workplace change was designed and conducted by the organization, with support from external consultants. It was implemented by a multisectoral project organization and managed by a steering group that comprised representatives from the top and middle management, as well as consultants. A user group coordinated the implementation and was responsible for the practical arrangements. This group contained representatives from all units: human resource $(\mathrm{HR})$, facility management, the information and communication technology unit, financial administration and substance departments. A core group, which was coordinated by the project manager, consisted of members of the steering group and the user group. Other groups also handled communication and supervised renovation (especially the indoor environment, acoustics and energy efficiency). Specialists and architects from a workplace development consultancy supported the process. These consultants arranged workshops and seminars on change management and personnel participation.

The researchers were not involved in the implementation or the planning. Their role was to evaluate the process of change and to conduct interviews and questionnaires. In addition to our surveys, the consultants conducted surveys to support the planning process.

The reasons for the change stemmed from the Government Premises Strategy 2020 (The Ministry of Finance, 2014) and the need to renovate the premises. The key idea of the organization's strategic change goals was to enable work across sector and ministry boundaries, according to new priorities: to minimize environmental impact by using efficient space solutions. These new spatial solutions and ways of promoting interaction were means to support the achievement of the strategic goals. Based on these objectives, a work environment vision was formed (Figure 1).

The new office was located in a different building to the private offices; an old seven-floor building, which had been renovated into an ABO. The organization aimed for $18 \mathrm{~m}^{2} / \mathrm{FTE}$, which is the target for renovated office facilities in Finland [the Government Premises Strategy 2020 (The Ministry of Finance, 2014)]. Figure 2 presents the typical layout of the floors. The workstations were located in different zones: a semi-quiet area, a quiet area, skype rooms, an informal interaction area, meeting rooms and a recreation room. The employees had assigned desks but could use different areas according to their activities. Ground rules were drawn up for all areas. The workstations were partitioned by screens and equipped with computer screens, keyboards, mice and wireless internet.

\section{Data gathering and participants}

A modified Work Environment and Well-being Survey (Ruohomäki et al., 2013) that covered several themes related to the physical and psychosocial work environment and work 
$\mathrm{F}$

$40,15 / 16$

environmental change was sent electronically to 293 employees of the organization three months before the relocation and to 236 employees 12 months after the relocation. The response rate was $53 \%(n=154)$ before and $62 \%(n=146)$ after the relocation. In total, 105 employees participated in both surveys and their data were used in the analyses. Three respondents $(2.9 \%)$ had worked in a shared room before the relocation but the majority had had private offices. The respondents who dropped out after the relocation was, on average, 4.5 years younger than the respondents who participated in both surveys, but they did not differ statistically significantly in terms of other background factors. Table 1 shows the respondents' descriptive information.

The interviews were conducted a month before the relocation. At the time, the change process had been in progress for two years. The qualitative material consisted of the theme

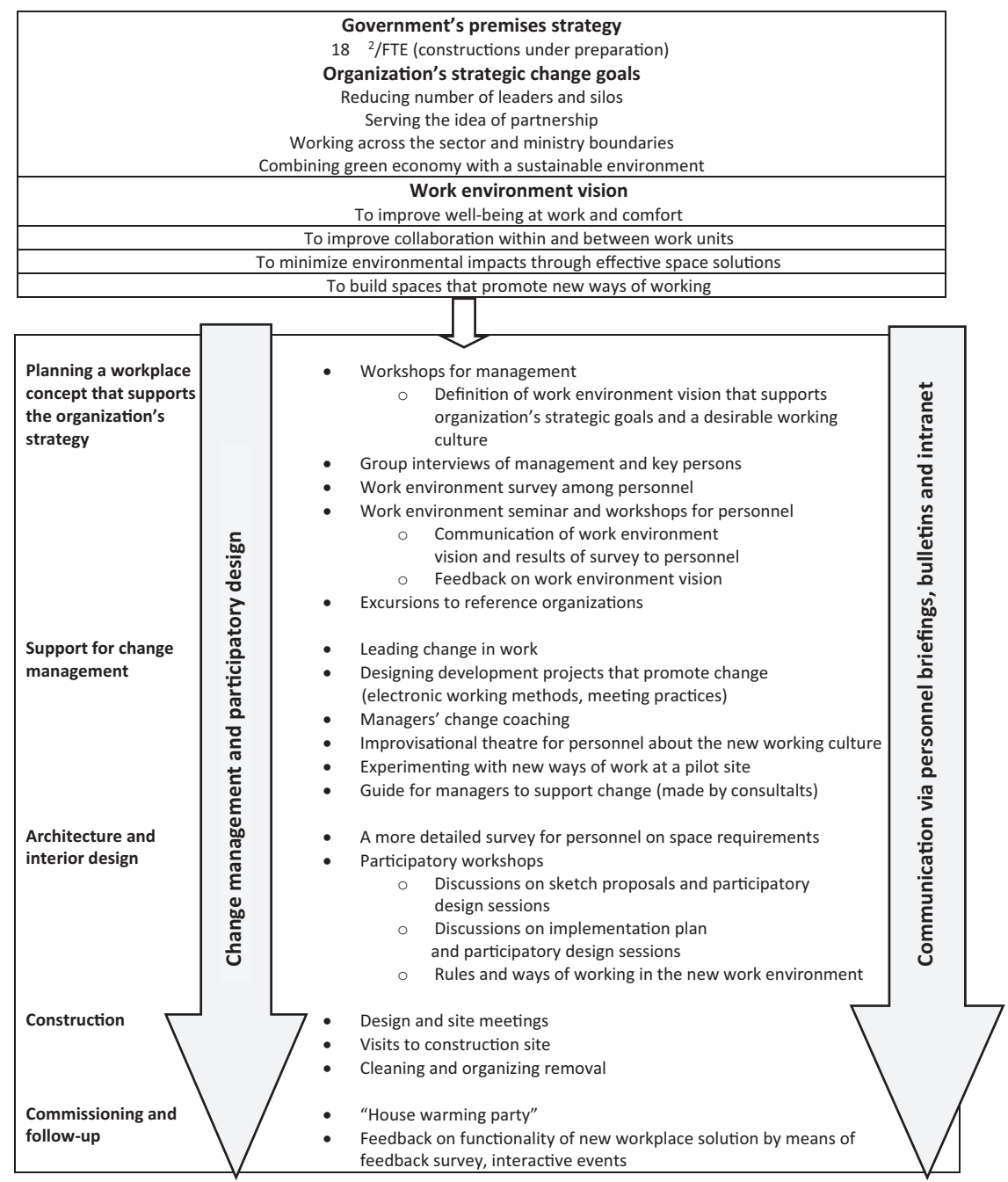

Figure 1.

Workplace change process 
interviews ( $n=17$ ) of the representatives of different units (employees, including managers) who were involved in the implementation process. The structure of the interviews followed the steps of a successful change process (Lahtinen et al., 2015, 2017; Ruohomäki et al., 2015), focusing particularly on the negative and positive perceptions of the workplace change, as well as the roles of different stakeholders in the process. The interviews, which lasted approximately $1 \mathrm{~h}$ each, were audio recorded. In addition, documentary material (e.g. project plan, objectives, time schedules and layouts) was used to analyze and describe the stages of the change process and the participation of the different stakeholders in the different stages. This material was received at the end of 2014, at the beginning of the research project.

\section{Survey measures}

Environmental satisfaction was evaluated using a seven-point scale ("How satisfied are you with your work environment as a whole?"; 1 = very dissatisfied $-7=$ very satisfied). The questions measuring the perception of the change process were based on the successful process factors identified in the literature (Lahtinen et al., 2015, 2017). The following seven statements, with six response categories, were formulated $(1=$ completely disagree, $2=$ somewhat disagree, $3=$ neither agree nor disagree, $4=$ somewhat agree, $5=$ completely agree, 6 = do not know): "The management had good reasons for implementing a new office concept," "The management has provided clear information about the aims of the office renovation," "I find the aims easy to understand," "I have received sufficient information about the progress of the design of the new workspaces," "I have been sufficiently involved in the planning of the new premises," "I was able to influence the office design early enough before the plans were carried out" and "Personnel's views were taken into account well in the decision-making." The statements were preceded by a short text that reminded the respondents of the key objectives of the workplace change.

\section{Statistical methods}

The statistical analyses were conducted using IBM SPSS Statistics 25 (Armonk, NY: IBM Corp). Due to some missing responses, the sample size varied from 85 to 101 in the different analyses. The change in environmental satisfaction between T1 (before relocation) and T2 (after relocation) was tested using the Wilcoxon Signed-Rank test. For the other analyses, we calculated a difference score for the change in environmental satisfaction by subtracting the rating of $\mathrm{T} 1$ from $\mathrm{T} 2$. Thus, positive change scores indicated improved satisfaction.

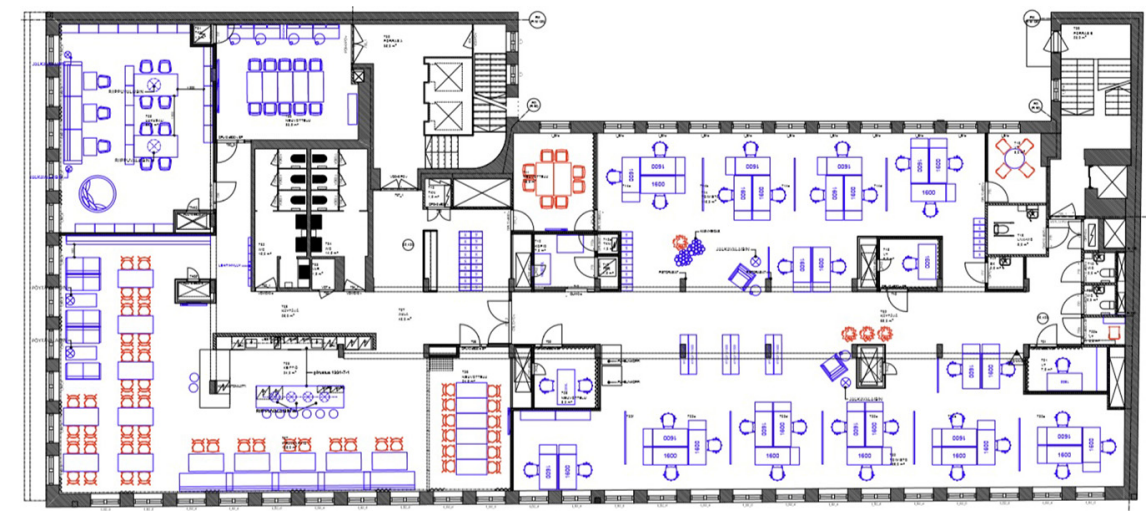

Figure 2. ABO layout 
$\mathrm{F}$

$40,15 / 16$

24

Spearman's correlation coefficients and logistic regression were used to test the extent to which the perception of different change process factors before the relocation was associated with the change in environmental satisfaction after the relocation. In the logistic regression, we formed two categories for the change in environmental satisfaction: a reference category indicating a decrease in environmental satisfaction $(\mathrm{T} 2<\mathrm{T} 1, n=51)$ and another category for no or a positive change in environmental satisfaction (T2 $\geq \mathrm{T} 1, n=45)$. For the statements measuring the perceptions of the change process, we excluded a sixth category ("do not know") which corresponded to $0-3.8 \%$ of responses, depending on the item. The remaining five categories were combined into the following three categories: the reference category "Disagree" (combining completely/somewhat disagree), "Neutral" (neither agree nor disagree) and "Agree" (combining completely/somewhat disagree). Logistic regression models were determined separately for each predictor (i.e. each statement concerning the change process) with the binary variable for the change in environmental satisfaction as the outcome. Unadjusted models, as well as models adjusted for age (as a continuous variable), gender and managerial position were reported. Odds ratios (ORs) were determined with $95 \%$ confidence intervals (CIs). Statistically significant ORs indicate an increase in the odds of no or positive change in environmental satisfaction after the relocation. The level of statistical significance was set at 0.05 .

\section{Qualitative analysis}

The recorded interviews were transcribed in the full and deductive content analysis was used to analyze them (Bengtsson, 2016). The answers were categorized by separating the negative and positive perceptions of the workplace change according to the successful process factors in the literature (Lahtinen et al., 2015, 2017; Ruohomäki et al., 2015) and then bringing together all the expressions of the same meaning and theming them. The documentary material was categorized deductively using material from project plans, written objectives, time schedules, layout drawings and interviews. The description of the process was based on this analysis (Figure 1).

\section{Results}

\section{Survey}

Descriptive analyses of perceptions of the change process and environmental satisfaction. The respondents varied greatly in how they perceived the different aspects of the change process before the relocation. Overall, the statements that addressed the sufficiency and clarity of information about the aims and the process were rated

Table 1. Sample characteristics

\begin{tabular}{lccc}
\hline Characteristic & Before & After & After* \\
\hline$n$ & 154 & 146 & 105 \\
Response rate, \% & 52.6 & 61.9 & \\
Age, M (SD) & $50.6(9.5)$ & $51.7(9.5)$ & $53.1(8.4)$ \\
Age, range & $27-68$ & $28-66$ & $28-66$ \\
Gender, female, \% & 70.1 & 75.3 & 72.4 \\
In a managerial position, \% & 14.6 & 10.8 & 15.5 \\
Length of employment, years, M (SD) & $12.7(9.8)$ & $13.3(10.0)$ & $13.9(9.2)$ \\
Education level, bachelor's degree or higher, \% & 90.2 & 88.7 & 88.4
\end{tabular}

Note: * Only respondents who answered at both time points were included in the analyses of questionnaire data 
more positively than the others and the proportion of respondents who agreed with these statements was higher than the proportion who disagreed (Figure 3). On the other hand, the respondents were particularly critical of their opportunities to influence the office design and the degree to which their views had been taken into account in

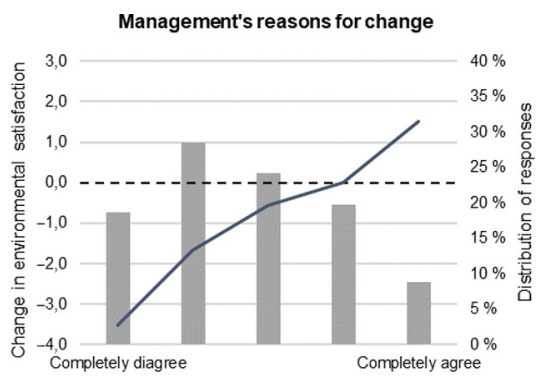

Clear information about the aims

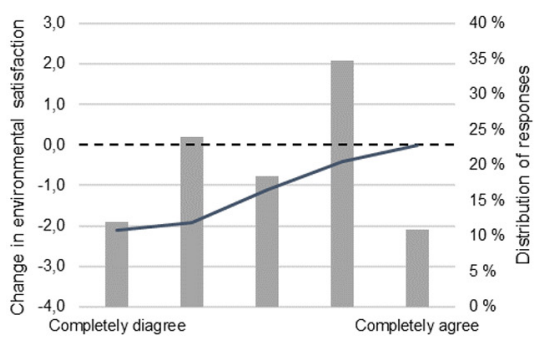

Aims are easy to understand

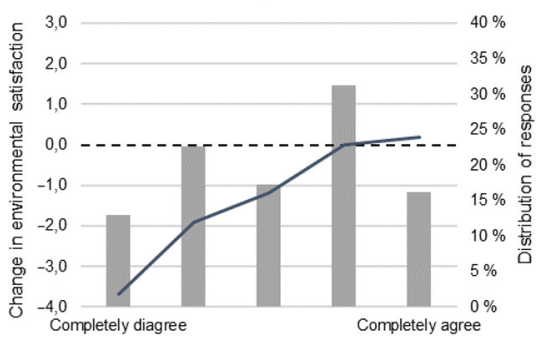

Sufficient information on the progress of workspace design

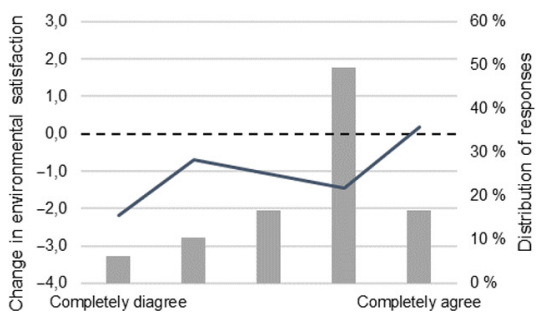

Sufficiently involved in the planning of new workspaces

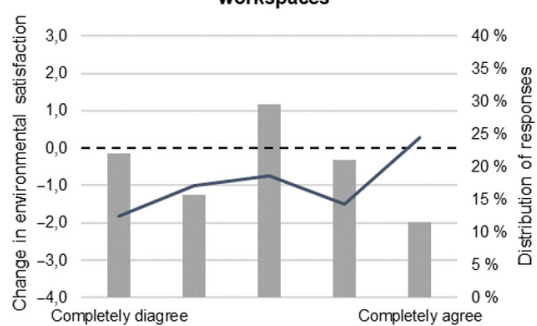

Have been able to influence the design

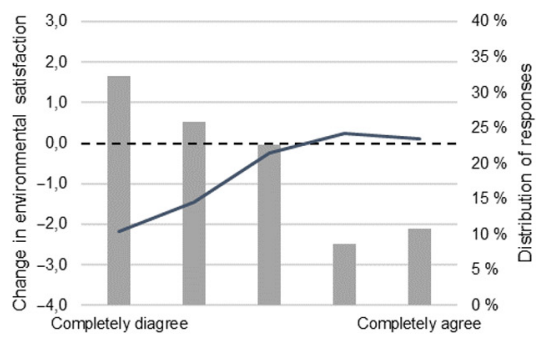

Personnel's views taken into account well

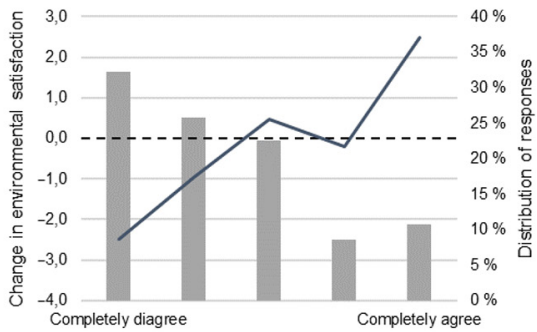

Figure 3.

The relation between the change in environmental satisfaction and respondents' perceptions of different factors of the change process before the relocation 
$\mathrm{F}$

$40,15 / 16$

26

decision-making (58\% disagreed on both). Nearly half of the respondents disagreed with the management's reasons for the change.

The difference score for the change in environmental satisfaction revealed large differences between individuals after the relocation, ranging from a six-unit decrease to a four-unit improvement. On average, environmental satisfaction decreased by 1.0 units.

Additional descriptive analyses showed that the respondents who were in a managerial position evaluated the change process statements more positively than the other respondents, except for the statement concerning receiving sufficient information on progress. For example, $44 \%$ of managers but only $7 \%$ of the other respondents perceived that their views had been taken into account well, while $69 \%$ of managers and $21 \%$ of other respondents agreed with the management's reasons for the change. Similarly, higher environmental satisfaction after the relocation was more common among the respondents who were in a managerial position $(38 \%)$ than among the others $(19 \%)$.

Associations between process factors and the change in environmental satisfaction. The within-participant comparisons of environmental satisfaction ratings in the pre- and postrelocation surveys showed that the decrease in satisfaction after the relocation was statistically significant $(\phi<0.001)$ (Table 2 ).

Table 2 comparison of pre- (T1) and post- (T2) relocation. Wilcoxon signed-rank test used $(n=96)$.

Table 3 shows the correlations between the perceptions of process factors before the relocation and the later change in environmental satisfaction.

The separate unadjusted logistic regression analyses for each statement showed that most process factors, except for information about progress and participation in the process, were associated with the change in environmental satisfaction (Table 4). That is, the odds of no change or a positive change in satisfaction were increased if the respondents agreed, before the relocation, that the management had good reasons for the change, that the management had provided clear information about the aims, that the aims were easy to understand, that the respondents had been able to influence the office design and that their views had been taken into account. For three of these statements (managements' reasons, opportunities to influence design and personnel's views being taken into account), neutral ratings were also associated with higher odds of no or a positive change in environmental satisfaction in comparison to disagreeing with the statements. The highest OR was observed for management's reasons for change, suggesting that it was the strongest predictor of a later change in environmental satisfaction.

The observed pattern of results persisted when the models were adjusted for age, gender and managerial position, although the ORs decreased slightly. Age and gender

Table 2.

Comparison between pre- (T1) and post (T2)-relocation. Wilcoxon signed-rank test used $(n=96)$

\begin{tabular}{lcccc}
\hline & $\mathrm{T} 1$ & $\mathrm{~T} 2$ & & \\
Variable & $\mathrm{M}(\mathrm{SE})$ & $\mathrm{M}(\mathrm{SE})$ & $z$ & $p$ \\
\hline Environmental satisfaction & $5.19(0.13)$ & $4.15(0.18)$ & -4.313 & $<0.001$ \\
Note: Environmental satisfaction (scale 1 = very dissatisfied $-7=$ very satisfied) & \\
\hline
\end{tabular}


were not associated with the change in environmental satisfaction. However, managers had higher odds $(\mathrm{OR}=4.6,95 \% \mathrm{CI}: 1.3 ; 16.3)$ of no or a positive change in environmental satisfaction than the other respondents. This effect disappeared in the models in which the predictor had a statistically significant relationship with the change in environmental satisfaction. This suggests that being in a managerial position was associated with a more positive perception of different process factors and that these perceptions were more relevant to environmental satisfaction than the managerial position as such.

\section{Documentary analysis and interviews}

Workplace change process. The organization had divided the change process into six phases on the basis of the qualitative analysis as follows:

(1) planning a workplace concept that supports the organization's strategy;

(2) architecture and interior design;

(3) construction;

(4) commissioning;

(5) follow-up; and

(6) support for change management, which was ongoing throughout the process (Figure 1).

The forums for change management and participation included a workplace survey for the personnel during the planning phase and design phase, interviews of key persons, various workshops (e.g. workshops for design and planning of rules), seminars for management and other employees and improvised theatre performance, excursions and a follow-up survey

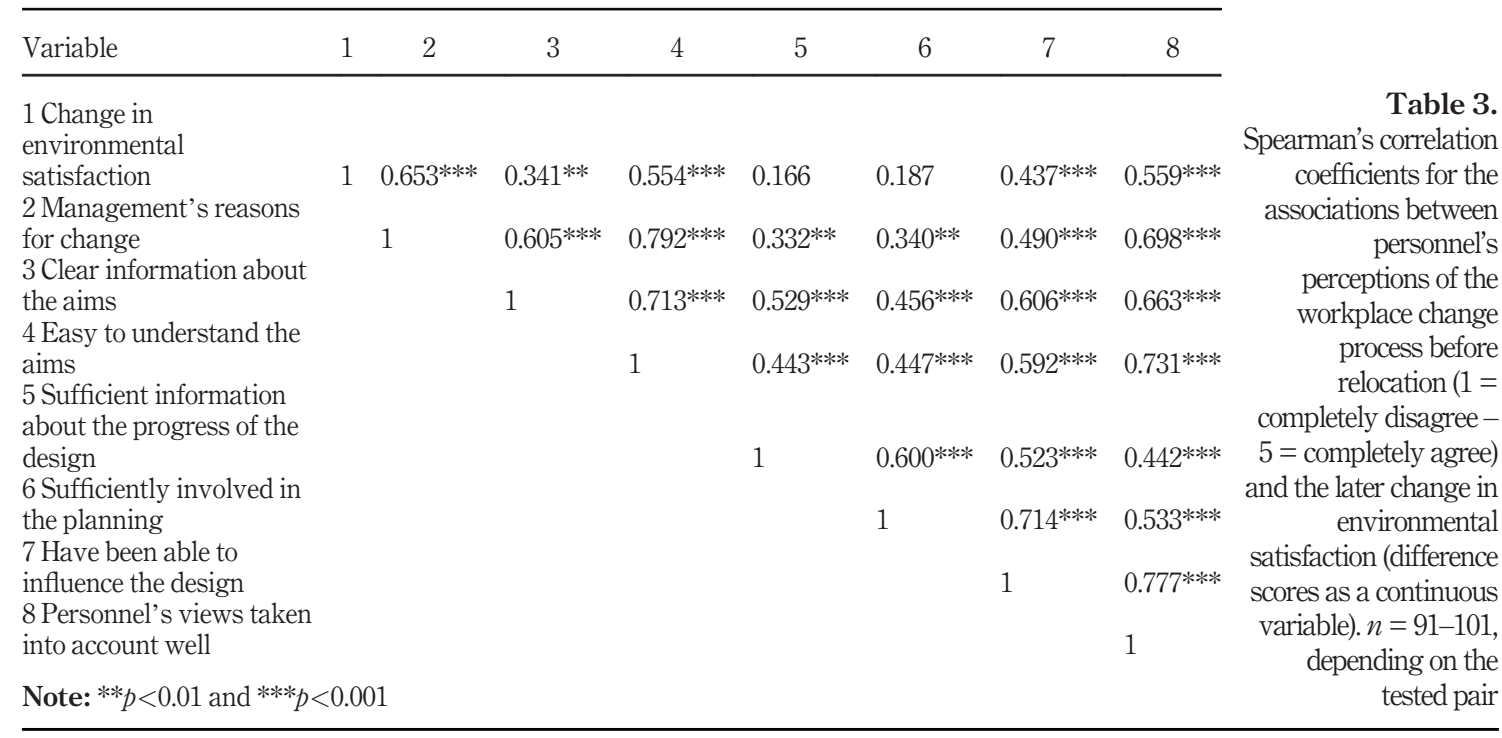


F

$40,15 / 16$

28

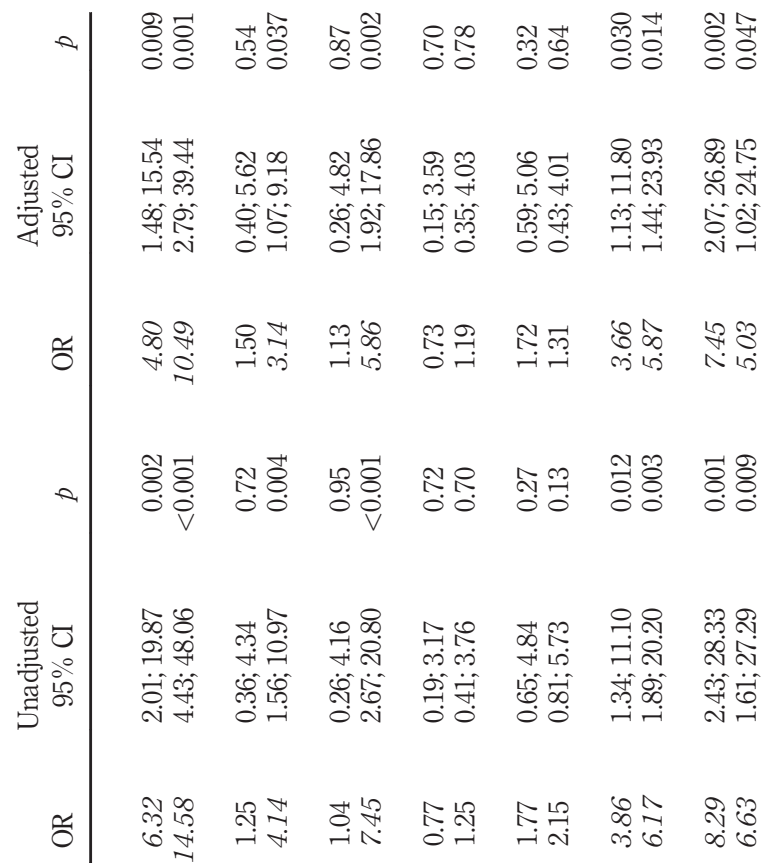

:

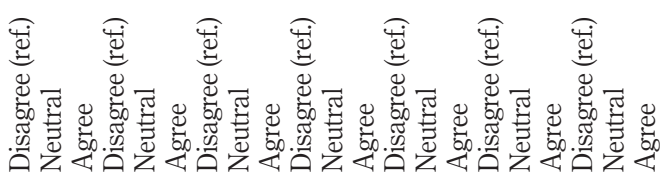

Table 4.

The associations between the perception of different factors related to the change process before the relocation and the change in environmental satisfaction after relocation. Odds ratios with lower and upper 95\% confidence limits and $p$-values are reported. The adjusted model includes age, gender and managerial position as covariates. $n$ $=85-95$, depending on the predictor and model

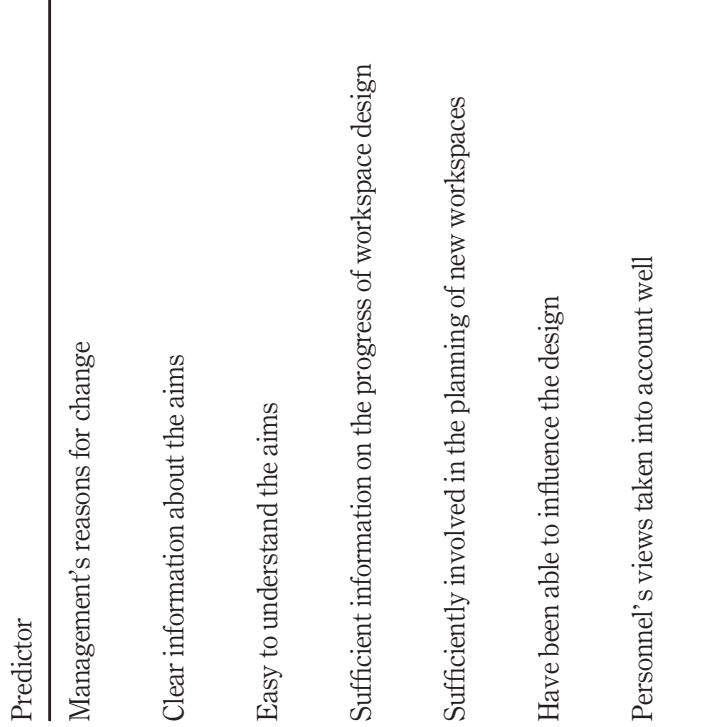



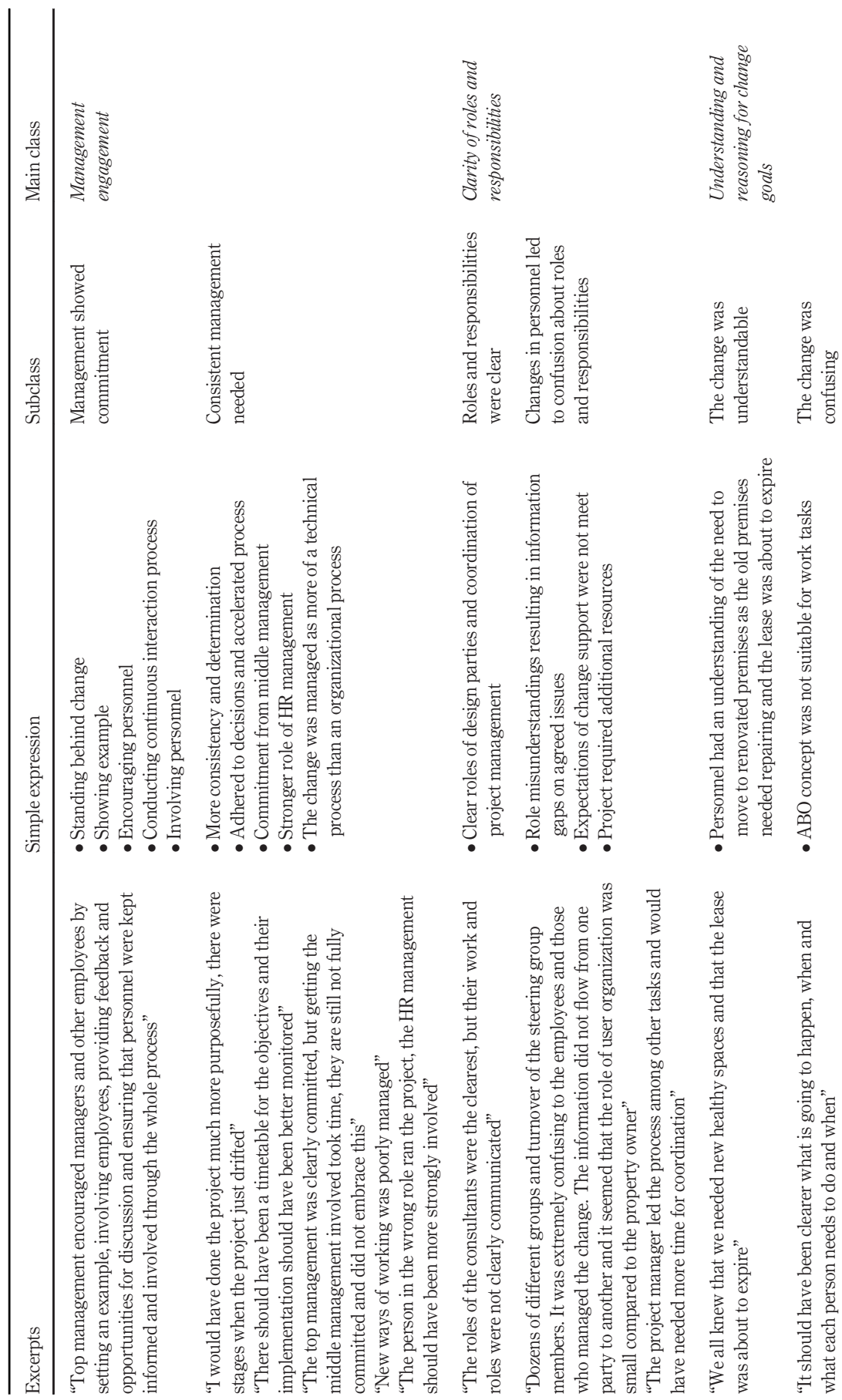

29

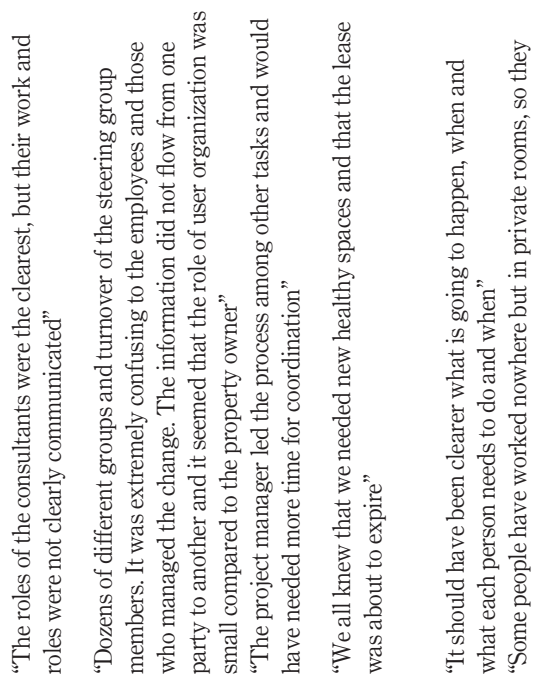

Table 5.

Results of the interviews 


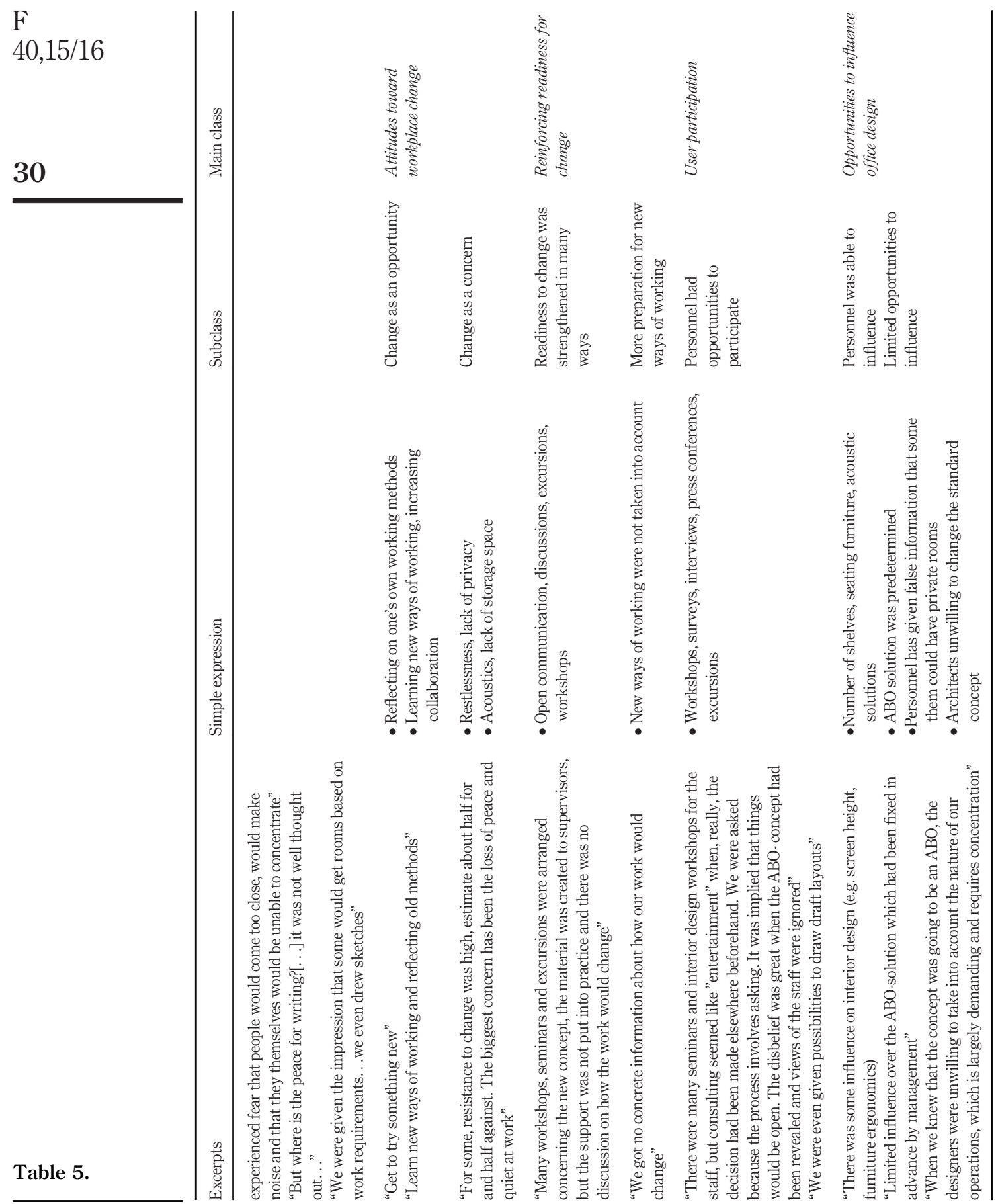


conducted by the researchers. Communication was supported by briefings, bulletins and the intranet. The workplace survey and most of the events were arranged and facilitated by a workplace development consultancy. Supervisor training was also held and a guide for supervisors was prepared to support change management.

Results of the interviews. The resulting main categories were: management commitment, clarity of roles and responsibilities in the project organization, understanding and reasoning of the goals of the change, attitudes toward workplace change, reinforcing readiness for change, user participation and opportunities to influence design. These main categories were divided into subcategories (Table 5).

Management engagement and clarity of roles and responsibilities. Many of the interviewees perceived that management showed commitment by standing behind the change and showing an example, encouraging managers and other employees and conducting a continuous interaction process. However, even though top management was highly committed to the change and acted as an example, some of the interviewees felt that the organization's management could have been more consistent and determined. A common theme in the interviews was that the process should have been quicker and the decisions made should have been adhered to. In addition, more commitment was required of middle management. Many of the interviewees felt that the change was managed as more of a technical than a people-oriented process, meaning that they felt that the leaders had not sufficiently considered the needs of the personnel. They perceived that the leaders' main focus had been to get a new concept ready in time and to promote the strategy; they did not look at the concept from the perspective of the individual's needs or help the personnel understand how their work was going to change under the new concept. More preparation for new working methods was needed and HR management should have played a stronger role in this.

Even though roles and responsibilities were mostly clear to the interviewees, changes in the steering group caused confusion about them, which in turn weakened the communication between the steering group and the other groups. Moreover, most of the interviewees felt that the project manager would have needed more resources to better coordinate the process overall.

Understanding of and reasoning for goals of change. Many interviewees understood the reason for moving to new premises, because the old premises were in need of repair. Contradictions arose from the suitability of the ABO for the demands of their work, which in turn affected the extent to which the interviewees considered the reasons for the change to be justified. Many interviewees reported that they had been informed that they could have private rooms, which they considered the best solution in terms of the demands of their work.

Attitudes toward workplace change and reinforcing readiness for change. Attitudes toward workplace change varied. Some respondents saw the change as a new opportunity, whereas others strongly resisted it; they were particularly afraid of restlessness and a lack of privacy and they doubted that the premises would be suitable for their work.

The readiness for change was strengthened by, for example, open communication, discussions with the personnel, problem-solving, creating material to support change for the managers, excursions and workshops. However, most interviewees reported that more preparation would have been needed for new working methods.

User participation and opportunities to influence design. Most of the interviewees felt that personnel had been given extensive opportunities to participate in the process, but limited opportunities to influence design. Many workshops, surveys and interviews were arranged and the personnel was given the impression that some of them could have private 
$\mathrm{F}$

$40,15 / 16$

rooms and were given opportunities to draw draft layouts. When the ABO concept had been introduced, the interviewees felt that the designers had been unwilling to change the standard concept (e.g. inadequate privacy protection, height of workstation furniture). For this reason, the interviewees felt that the demands of their work were not sufficiently taken into account in the design of the $\mathrm{ABO}$.

\section{Discussion}

This study examined the effects of workplace change and the management of change on environmental satisfaction in an organization that moved from private offices to an ABO. Our study is rare in that it investigated both the process and its relationship with later satisfaction with the workspaces by combining quantitative and qualitative research. The results showed that, on average, environmental satisfaction decreased in the $\mathrm{ABO}$, which is in line with similar relocation studies (Haapakangas et al., 2018; Ruohomäki et al., 2019). Second, the perceptions of the process before the relocation were associated with a change in environmental satisfaction even a year after the relocation took place, complementing earlier studies, which have shown associations between the implementation process and employee satisfaction (Brunia et al., 2016; Rolfö et al., 2018; Wijk et al., 2020). In this case study, the personnel perceived shortcomings in change management, especially in their opportunities to really influence the decision-making and design process, as well as to receive accurate information. These experiences contributed to negative perceptions of the process and a decrease in environmental satisfaction at one-year follow-up.

Our findings emphasize the potential long-term implications of the quality of the implementation process and are unique in that they report an association between the perceived change management before the workplace change and environmental satisfaction 12 months after the relocation. These results are parallel with the findings of Bergsten et al. (2021), who showed that the level of change-oriented leadership prior to an office redesign later moderated the effects of workspace change on self-rated productivity. As in our study, this association continued 12 months after moving to an ABO. The personnel's degree of agreement with the management's reasons for the change had the strongest relation to the change in environmental satisfaction, which is in line with the findings of Wijk et al. (2020). They found that the level of agreement with the organization's vision of the office change moderated satisfaction with both the physical and psychosocial environment, although the follow-up time (9 months) was shorter than that in our study. Other studies that have not considered the implementation process have found ABOs to have negative effects on communication and quantitative and emotional work demands in a similar 12-month followup (Haapakangas et al., 2019). Combined with what is known from these previous studies, the quality of change management appears to be relevant to the various long-term outcomes that are related to employee satisfaction, well-being and productivity.

Another factor that our findings underline is the high quality of change management required, particularly regarding communication and user participation in terms of real decision power. Environmental satisfaction only appeared to improve among those who completely agreed that the management had good reasons for the change and that the personnel's views had been taken into account well in the decision-making (Figure 3); that is, agreeing only partly or completely with other statements was not associated with improved environmental satisfaction. Receiving information about the progress of the design and being sufficiently involved in the planning process was not associated with the effects of the relocation on environmental satisfaction in the survey data. Although providing information and involving employees have been generally regarded as beneficial factors in workplace change management (Lahtinen et al., 2015; Rolfö et al., 2018), these elements need 
specification in terms of quality and content (Bull and Brown, 2012). User participation can raise false expectations if not managed well, in turn, leading to negative outcomes (Visher, 2012), as was the case in our study, as the personnel received misinformation regarding the possibility of keeping their private offices. This may have undermined their trust in the management and increased their resistance to change (Laframbroise et al., 2003; Finch, 2012). Furthermore, the personnel perceived the ABO as being incompatible with the demands of their work, which likely contributed to the perception of low influence and dissatisfaction with the workplace change, particularly as feedback had been gathered from the personnel, raising hopes of being able to influence the design. Moreover, as the interviews showed, the process may have been technically driven, perhaps, leading to poor dialogue between the organization and the consultants, and thus less attention to the personnel's context and needs.

The survey results showed that the managers were more likely to maintain their level of satisfaction or even experience an improvement than the other respondents. This improvement was related to the managers' more positive perceptions of the change process and not their managerial position as such. Due to their position in the organization, the managers were probably more active participants in the process and had more access to information and support from the consultants and upper management, whereas other employees may have needed more preparation for new working methods. This highlights the need to help employees adopt a new working style for the ABO (Brunia et al., 2016).

Interestingly, a high proportion of the managers felt that the views of the personnel had been taken into account well, but the employees thought the opposite. This may reflect a failure to recognize one's "privileged position" in the process, to empathize with the employees' needs or to adjust their management style accordingly. Thus, the managers may have looked at the benefits of the change more from the organization's perspective than from the individuals' point of view, as suggested in Kämpf-Dern and Konkol (2017). In the interviews, the personnel expected greater commitment from middle management in particular, as they play an important role in communicating information top-down and bottom-up, thus enhancing the quality of organizational communication in a workplace change (Brunia et al., 2016).

In addition to change management, the decrease in environmental satisfaction likely also relates to the fact that the ABO design sub-type included assigned desks. Some crosssectional studies suggest that flexible desk use may be associated with higher employee satisfaction and well-being in ABOs (Bodin Danielsson and Bodin, 2008, 2009; Kim et al., 2016). The preceding office type is also relevant to environmental satisfaction in an ABO. Employees in private offices are generally fairly satisfied with their work environment (Bodin Danielsson and Bodin, 2009; De Been and Beijer, 2014), and thus, may not feel the need for a workplace change. In this study, some of the interviewees resisted the change and were particularly afraid of restlessness and a lack of privacy - factors that have been found to decrease environmental satisfaction in a similar context (Haapakangas et al., 2018). Positive outcomes have been previously observed among employees moving to an ABO from shared (Gerdenitsch et al., 2017; Meijer et al., 2009) or open-plan offices (Van der Voordt, 2004; Blok et al., 2009; Arundell et al., 2018). Therefore, the quality of change management is especially important when implementing an $\mathrm{ABO}$ in an organization in which private offices have been the norm.

Our results raise the question of which sectors and types of organizations would benefit from an ABO design. The studied organization was from the public sector, in which the transformation of organizational practices and working methods may be more challenging. The ABO was originally developed for mobile and multilocational work and may be easier 
$\mathrm{F}$

$40,15 / 16$

to adopt in organizations in which the way of working has already transformed. Based on other studies, organizations working in traditional open-plan offices might also benefit from moving to ABOs, through improved user satisfaction with working conditions (Engelen et al., 2019). However, as COVID-19 has accelerated multilocational working in sectors in which office presence was previously emphasized, developing the ABO concept to benefit different types of organizations may have potential. Future studies are needed to investigate which types of organizations benefit most from ABOs.

The strengths of this study include its use of both qualitative and quantitative methods, which reinforces the results by providing complementary data. The results of this study also contribute to the literature on $\mathrm{ABO}$ design that has examined $\mathrm{ABO}$ s with assigned desks in only a few previous relocation studies (Lahtinen et al., 2015; Ruohomäki et al., 2017; Haapakangas et al., 2018). In addition, the follow-up time of 12 months was longer than in many other ABO studies (Gerdenitsch et al., 2017; Morrison and Stahlmann-Brown, 2021). However, as in all case studies, caution is needed when generalizing these results to other organizations. We also note that the long-term changes in environmental satisfaction may not be related only to change management preceding the relocation, as negative perceptions of managerial support may have continued after moving to the ABO. In addition, due to the sample size and the skewed distributions in many variables, more detailed statistical analyses were not possible. For these reasons, we were unable to focus on improved environmental satisfaction as the outcome and had to place it in the same category as no change in satisfaction level. Future studies could specifically investigate the factors that contribute to improved employee satisfaction when implementing ABOs.

Our results have several implications for both $\mathrm{ABO}$ research and practice. They demonstrate the importance of a multi-method approach and the consideration of process factors when quantitatively evaluating $\mathrm{ABO}$ s in relation to other office types. As the perceptions of the process of implementation were associated with perceptions of the work environment even a year after the relocation, researchers comparing ABOs to other office types should be aware of the impact of the change process. Conclusions about the quality of the physical office design may be unreliable if the office redesign is recent and the change process is not considered. The change process may play an even larger role in the perception of office spaces in the short term. Thus, longer follow-up times are recommended for future studies.

In terms of practical implications, our results highlight the importance of recognizing the implementation of an $\mathrm{ABO}$ as an organizational change that requires substantial managerial involvement and high-quality change management. The ABO concept tends to be introduced in companies with very positive expectations (van Koetsveld and Kamperman, 2011), which may lead management to overlook context-specific challenges in the implementation and the amount of managerial support needed. Special care should particularly be taken in organizations in which the personnel has previously worked in private offices. As other studies have also linked inadequate change management to negative long-term consequences for employees (Rolfö, 2018; Wijk et al., 2020; Bergsten et al., 2021), organizations should also monitor user experiences and need systematically after office redesign and take corrective action as needed. Top management needs to ensure that goals are communicated clearly to all the parties before planning the workplace change concept, that they are followed as planned and that no exemptions are granted without clear justifications. Personnel needs to be engaged from the very beginning of the process by giving them not only opportunities to participate in it but also opportunities to influence it within the limits set by, for example, technical and economic factors. Middle managers should be sensitive to the fact that their subordinates may experience change differently to them, thus supporting their sense of coherence and better preparing them for new working methods long before the actual relocation. 


\section{Conclusion}

Relocating from a private office to an $\mathrm{ABO}$ is challenging for employees and requires a great deal from change management. People-oriented leadership plays a key role in this. Conclusions about the quality of the $\mathrm{ABO}$ itself should be drawn cautiously if change management is not taken into account, as it contributes to the perception of the work environment even a year after the relocation. Thus, longer follow-up times are also necessary for future studies. To support satisfaction with the work environment, special attention should be paid to communicating and discussing the reasons for the change, preparing the personnel for the new office concept and the changes to work and offering them real opportunities to influence.

\section{References}

Antonovsky, A. (1996), "The salutogenic model as a theory to guide health promotion", Health Promotion International, Vol.11 No. 1, pp. 11-18.

Appel-Meulenbroek, R., Groenen, P. and Janssen, I. (2011), "An end-user's perspective on activity-based office concepts", Journal of Corporate Real Estate, Vol. 13 No. 2, pp. 122-135, doi: 10.1108/14630011111136830.

Arundell, L., Sudholz, B., Teychenne, M., Salmon, J., Hayward, B., Healy, G.N. and Timperio, A. (2018), "The impact of activity-based working (ABW) on workplace activity, eating behaviours, productivity and satisfaction", International Journal of Environmental Research and Public Health, Vol. 15 No. 5, p. 1005.

Babapour, M.C. (2019), "The quest for the room of requirement. Why some activity-based flexible offices work while others do not", $\mathrm{PhD}$ thesis. Chalmers University of Technology.

Bengtsson, M. (2016), "How to plan and perform a qualitative study using content analysis", Nursingplus Open, Vol. 2, pp. 8-14, doi: 10.1016/j.npls.2016.01.001.

Bergsten, E.L., Haapakangas, A., Larsson, J., Jahncke, H. and Hallman, D. (2021), "Effects of relocation to activity-based workplaces on perceived productivity: importance of change-oriented leadership", Applied Ergonomics, Vol. 93, p. 103348.

Blok, M., Groenesteijn, L., Schelvis, R. and Vink, P. (2012), "New ways of working: does flexibility in time and location of work change work behaviour and affect business outcomes?”, Work, Vol. 41, pp. 2605-2610, doi: 10.3233/WOR-2012-1028-2605.

Blok, M., de Korte, E., Groenesteijn, L., Formanoy, M. and Vink, P. (2009), "The effects of a task facilitating environment on office space use, communication, concentration, collaboration, privacy and distraction", Proceedings of the 17th World Congress on Ergonomics in Beijing, 9.8-14.8.2009, International ergonomics association.

Bodin Danielsson, C. and Bodin, L. (2008), "Office type in relation to health, well-being and job satisfaction among employees", Environment and Behavior, Vol. 40 No. 5, pp. 636-668.

Bodin Danielsson, C. and Bodin, L. (2009), "Difference in satisfaction with office environment among employees in different office types", Journal of Architectural and Planning Research, Vol. 26 No. 3, pp. 241-257.

Bodin Danielsson, C., Bodin, L., Wulff, C. and Theorell, T. (2015), "The relation between office type and workplace conflict: a gender and noise perspective", Journal of Environmental Psychology, Vol. 42, pp. 161-171.

Brunia, S., de Been, I. and van der Voordt, T.J. (2016), “Accommodating new ways of working: lessons from best practices and worst cases”, Journal of Corporate Real Estate, Vol. 18 No. 1, pp. 30-47, doi: 10.1108/JCRE-10-2015-0028.

Bull, M. and Brown, T. (2012), "Change communication: the impact on satisfaction with alternative workplace strategies”, Facilities, Vol. 30 Nos 3/4, pp. 135-151, doi: 10.1108/02632771211202842.

De Been, I. and Beijer, M. (2014), "The influence of office type on satisfaction and perceived productivity support", Journal of Facilities Management, Vol. 12 No. 2, pp. 142-157, doi: 10.1108/JFM-02-2013-0011.

Workplace
change process

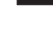


$\mathrm{F}$

$40,15 / 16$

De Been, I., Beijer, M. and Den Hollander, D. (2015), "How to cope with dilemmas in activity-based work environments - results from user-centred research", 14th EuroFM Research Symposium, EuroFM research papers, pp. 1-10, available at: www.researchgate.net/ publication/278952410_How_to_cope_with_dilemmas_in_activity_based_work_environments_ results_from_user-centred_research (accessed 15 June 2021).

De Croon, E., Sluiter, J., Kuijer, P. and Frings-Dresen, M. (2005), "The effects of office concepts on worker health and performance: a systematic review of the literature", Ergonomics, Vol. 48 No. 2 , pp. 119-134, doi: 10.1080/00140130512331319409.

Engelen, L., Chau, J., Young, S., Mackey, M., Jeyapalan, D. and Bauman, A. (2019), “Is activity-based working impacting health, work performance and perceptions? A systematic review", Building Research and Information, Vol. 47 No. 4, pp. 468-479, doi: 10.1080/09613218.2018.1440958.

Finch, E. (Ed.) (2012), Facilities Change Management, John Wiley and Sons, New York, NY.

Gerdenitsch, C., Korunka, C. and Hertel, G. (2017), "Need-supply fit in an activity-based flexible office: a longitudinal study during relocation”, Environment and Behavior, Vol. 50 No. 3, pp. 273-297, doi: $10.1177 / 0013916517697766$.

Golden, T. (2007), "Co-workers who telework and the impact on those in the office: understanding the implications of virtual work for co-worker satisfaction and turnover intentions", Human Relations, Vol. 60 No. 11, pp. 1641-1667, doi: 10.1177/0018726707084303.

Haapakangas, A., Hongisto, V., Varjo, J. and Lahtinen, M. (2018), "Benefits of quiet workspaces in openplan offices - evidence from two office relocations", Journal of Environmental Psychology, Vol. 56, pp. 63-75.

Haapakangas, A., Hallman, D., Mathiassen, S.E. and Jahncke, H. (2019), "The effects of moving into an activity-based office on communication, social relations and work demands - a controlled intervention with repeated follow-up", Journal of Environmental Psychology, Vol. 66, pp. 101-341.

Harris, R. (2016), "New organizations and new workplaces: implications for workplace design and management", Journal of Corporate Real Estate, Vol. 18 No. 1, pp. 4-16.

Hayes, J. (2018), “The Theory and Practice of Change Management”, 5th ed., Palgrave, New York, NY.

Herbig, B., Schneider, A. and Nowak, D. (2016), "Does office space occupation matter? The role of the number of persons per enclosed office space, psychosocial work characteristics and environmental satisfaction in the physical and mental health of employees", Indoor Air, Vol. 26 No. 5, pp. 755-767.

Hoendervanger, J.G., Van Yperen, N.W., Mobach, M.P. and Albers, C.J. (2019), "Perceived fit in activitybased work environments and its impact on satisfaction and performance", Journal of Environmental Psychology, Vol. 65, p. 101339, doi: 10.1016/j.jenvp.2019.101339.

Joroff, M.L. (2002), "Workplace mind shifts", Journal of Corporate Real Estate, Vol. 4 No. 3, pp. 266-274, doi: 10.1108/14630010210811886.

Kämpf-Dern, A. and Konkol, J. (2017), "Performance-oriented office environments - framework for effective workspace design and the accompanying change processes", Journal of Corporate Real Estate, Vol. 19 No. 4, pp. 208-238, doi: 10.1108/JCRE-03-2017-0009.

Kim, J., Candido, C., Thomas, L. and de Dear, R. (2016), "Desk ownership in the workplace: the effect of non-territorial working on employee workplace satisfaction, perceived productivity and health", Building and Environment, Vol. 103, pp. 203-214.

Kotter, J.P. (1996), “Leading Change”, Harvard Business School Press, Boston.

Laframboise, D., Nelson, R.L. and Schmaltz, J. (2003), "Managing resistance to change in workplace accommodation projects", Journal of Facilities Management, Vol. 1 No. 4, pp. 115-125.

Lahtinen, M., Ruohomäki, V. and Sirola, P. (2017), "Good practices and development needs of workplace change management”, in Järvelin-Pasanen, S. (Ed.), NES 2016 - Ergonomics in Theory and Practice. Proceedings of 48th Annual Conference of Nordic Ergonomics and Human Factors 
Society, Publications of the Eastern University of Finland, Reports and Studies in Health Science, Kuopio, pp. 110-115.

Lahtinen, M., Ruohomäki, V., Haapakangas, A. and Reijula, K. (2015), "Developmental needs of workplace design practices", Intelligent Buildings International, Vol. 7 No. 4, pp. 198-214, doi: 10.1080/17508975.2014.1001315.

Lee, S.Y. and Brand, J.L. (2005), "Effects of control over office workspace on perceptions of the work environment and work outcomes", Journal of Environmental Psychology, Vol. 25 No. 3, pp. 323-333.

Lewin, K. (1951), Field Theory in Social Science, Harper and Row, New York, NY.

Meijer, E.M., Frings-Dresen, M.H. and Sluiter, J.K. (2009), "Effects of office innovation on office workers' health and performance”, Ergonomics, Vol. 52 No. 9, pp. 1027-1038.

Morrison, R.L. and Stahlmann-Brown, P. (2021), "Perceptions and performance of knowledge workers transitioning from single-cell offices to shared workspaces: evidence from panel data", Journal of Managerial Psychology, Vol. 36 No. 4, pp. 366-381.

Nemecek, J. and Grandjean, E. (1973), "Results of an ergonomic investigation of large-space offices", Human Factors: The Journal of the Human Factors and Ergonomics Society, Vol. 15 No. 2, pp. 111-124.

Newsham, G., Brand, J., Donnelly, C., Veitch, J., Aries, M. and Charles, K. (2009), "Linking indoor environment conditions to job satisfaction: a field study", Building Research and Information, Vol. 37 No. 2, pp. 129-147.

Nielsen, K. and Randal, R. (2013), "Opening the black box: presenting a model for evaluating organizational level interventions", European Journal of Work and Organizational Psychology, Vol. 22 No. 5, pp. 601-617, doi: 10.1080/1359432x.2012.690556.

Nijp, H.H., Beckers, D.G.J., van de Voorde, K., Geurts, S.A.E. and Kompier, M.A.J. (2016), "Effects of new ways of working on work hours and work location, health and job-related outcomes", Chronobiology International, Vol. 33 No. 6, pp. 604-618, doi: 10.3109/07420528.2016.1167731.

Oldham, G.R. and Brass, D.J. (1979), "Employee reactions to an open-plan office: a naturally-occurring quasi-experiment”, Administrative Science Quarterly, Vol. 24 No. 2, pp. 267-284.

Pejtersen, J., Allermann, L., Kristensen, T.S. and Poulsen, O.M. (2006), "Indoor climate, psychosocial work environment and symptoms in open-plan offices", Indoor Air, Vol. 16 No. 5, pp. 392-401.

Robertson, M.M., Huang, Y.H., ÓNeill, M.J. and Scheifer, L.M. (2008), " "Flexible workspace design and ergonomics training: Impacts on the psychosocial work environment, musculoskeletal health and work effectiveness among knowledge workers", Applied Ergonomics, Vol. 39 No. 4, pp. 482-494.

Rolfö, L. (2018), "Relocation to an activity-based flexible office - design processes and outcomes", Applied Ergonomics, Vol. 73, pp. 141-150, doi: 10.1016/j.apergo.2018.05.017.

Rolfö, L., Eklund, J. and Jahncke, H. (2018), "Perceptions of performance and satisfaction after relocation to an activity-based office", Ergonomics, Vol. 61 No. 5, pp. 644-657, doi: 10.1080/ 00140139.2017.1398844.

Ruohomäki, V., Haapakangas, A. and Lahtinen, M. (2013), "Tilat työn mukaisiksi: työn analyysi ja koettu sisäympäristö yliopistossa”, Sisä̈lmayhdistys ja Aalto-Yliopisto, SIY Raportti, Vol. 31, pp. 135-140. Sisäilmastoseminaari 2013.

Ruohomäki, V., Lahtinen, M. and Reijula, K. (2015), "Salutogenic and user-centred approach for workplace design”, Intelligent Buildings International, Vol. 7 No. 4, pp. 184-197, doi: 10.1080/ 17508975.2015.1007911.

Ruohomäki, V., Lahtinen, M. and Sirola, P. (2017), “Työympäristömuutos, monitilatoimiston toimivuus ja henkilöstön hyvinvointi”, Työelämän Tutkimus, Vol. 15 No. 2, pp. 3-28.

Ruohomäki, V., Sirola, P. and Lahtinen, M. (2019), "Perceptions of satisfaction, collaboration, well-being and productivity after relocation to an activity-based office", Broberg, Ole and Seim, Rikk, 50th Nordic Ergonomics and Human Factors Society Conference 2019, Denmark DTU Management, Technical University of Denmark, Denmark. 
$\mathrm{F}$

$40,15 / 16$

Ruohomäki, V., Lahtinen, M., Joutsiniemi, A., Airaksinen, M., Tuominen, P. and Kekäläinen, P. (2015), "Human and green workplace design in the university", in Nenonen, S., Kärnä, S., Junnonen, J.M., Tähtinen, S. and Sandström, N. (Eds), Oppiva kampus - How to co-Create Campus?, Suomen Yliopistokiinteistöt, Tampere, pp. 166-181.

Seddigh, A., Berntson, E., Bodin Danielson, C. and Westerlund, H. (2014), "Concentration requirements modify the effect of office type on indicators of health and performance", Journal of Environmental Psychology, Vol. 38, pp. 167-174, doi: 10.1016/j.jenvp.2014.01.009.

The Ministry of Finance (2014), "Valtioneuvoston periaatepäätös valtion toimitilastrategiaksi 18.12.2014", Helsinki, avalable in Finnish from: https://vm.fi/documents/10623/307565/ Valtioneuvoston+periaatep $\% \mathrm{C} 3 \% \mathrm{~A} 4 \% \mathrm{C} 3 \% \mathrm{~A} 4 \mathrm{t} \% \mathrm{C} 3 \% \mathrm{~B} 6 \mathrm{~s}+$ valtion+toimitilastrategiaksi/ 0a92ff49-8d57-43fe-b49a-ae911c98b59d

Van der Voordt, D.J.M. (2003), Cost and Benefits of Innovative Workplace Design, Delft University of Technology, Faculty of Arhitecture, Dept. of Real Estate and Housing, Delft.

Van der Voordt, T.J.M. (2004), "Productivity and employee satisfaction in flexible workplaces", Journal of Corporate Real Estate, Vol. 6 No. 2, pp. 133-148.

Van der Voordt, T.J.M., de Been, I. and Maarleveld, M. (2012), "Post-occupancy evaluation of facilities change", in Finch E. (Ed.), Facilities Change Management, Blackwell Publishing, Oxford, pp. 137-154.

van Koetsveld, R. and Kamperman, L. (2011), "How flexible workplace strategies can be made successful at the operational level”, Corporate Real Estate Journal, Vol. 1 No. 4, pp. 303-319.

Vartiainen, M., Hakonen, M., Koivisto, S., Mannonen, P., Nieminen, M.P., Ruohomäki, V. and Vartola, A. (2007), Distributed and Mobile Work - Places, People and Technology, University Press, Helsinki.

Visher, J.C. (2012), "Empowerment in workspace change", in Finch, E. (Ed.), Facilities Change Management, John Wiley and Sons, New York, NY, pp. 123-136.

Wijk, K., Bergsten, E.L. and Hallman, D.M. (2020), "Sense of coherence, health, well-being and work satisfaction before and after implementing Activity-Based workplaces", International Journal of Environmental Research and Public Health, Vol. 17 No. 14, p. 5250, doi: 10.3390/ijerph17145250.

Wohlers, C. and Hertel, G. (2017), "Choosing where to work at work-towards a theoretical model of benefits and risks of activity-based flexible offices", Ergonomics, Vol. 60 No. 4, pp. 467-486, doi: 10.1080/00140139.2016.1188220.

Wohlers, C., Hartner-Tiefenthaler, M. and Hertel, G. (2019), "The relation between activity-based work environments and office workers' job attitudes and vitality", Environment and Behavior, Vol. 51 No. 2, pp. 167-198, doi: 10.1177/0013916517738078.

Zalesny, M.D. and Farace, R.V. (1987), "Traditional versus open offices: a comparison of sociotechnical, social relations and symbolic meaning perspectives", Academy of Management Journal, Vol. 30 No. 2, pp. 240-259.

\section{Further reading}

Neves, P. (2009), "Readiness for change: contributions for employees level of individual change and turnover intentions", Journal of Change Management, Vol. 9 No. 2, pp. 215-231.

\section{About the authors}

Pia Sirola, MA (Educ.), is a specialist at the Finnish Institute of Occupational Health, Helsinki, Finland. Her recent projects have focused on good practices of workplace change, experienced functionality and well-being of users in the new office-, hospital- and elderly care working environments. Pia Sirola is the corresponding author and can be contacted at:pia.sirola@ttl.fi

Annu Haapakangas $(\mathrm{PhD})$ is a Specialist Researcher at the Finnish Institute of Occupational Health, Helsinki, Finland. With a background in cognitive psychology and occupational health psychology, she specializes in the effects of office environments on human perceptions, well-being and productivity. Her expertise also includes the effects of office noise and room acoustics on 
cognitive performance and perceived work conditions. She has been involved in interdisciplinary research on the impacts of open office designs since 2007.

Marjaana Lahtinen $(\mathrm{PhD})$ works as a chief specialist at the Finnish Institute of Occupational Health (FIOH). She has specialized in work and organizational psychology. Her research interests are focused on psychosocial perspective to the indoor environment, participative design and workplace change management. She has worked at FIOH as a researcher and consultant since 1985.

Virpi Ruohomäki $(\mathrm{PhD})$ is a Senior Researcher at the Finnish Institute of Occupational Health (FIOH). She is specialized in work and organizational psychology. Her research areas are new ways of working, new working environments, knowledge work, leadership and change management. She has worked at FIOH as a project manager since 2011 and previously in the Helsinki University of Technology (Aalto University) as a researcher and lecturer for 20 years.

For instructions on how to order reprints of this article, please visit our website: www.emeraldgrouppublishing.com/licensing/reprints.htm Or contact us for further details: permissions@emeraldinsight.com 